\title{
Antimicrobial TreatMent of „COMPLICATED“ INTRA-ABDOMINAL INFECTIONS AND THE NEW IDSA GUIDELINES - A Commentary and an Alternative European Approach ACCORding to Clinical Definitions
}

\author{
C. Eckmann 1 , M. Dryden², P. Montravers 3 , R. Kozlov ${ }^{4}$, G. Sganga ${ }^{5}$ \\ ${ }^{1}$ Department of General, Visceral and Thoracic Surgery, Klinikum Peine, Academic Hospital of Medical University Hannover, Germany \\ ${ }^{2}$ Royal Hampshire Hospital, Winchester, United Kingdom \\ ${ }^{3}$ Departement Anesthesie Reanimation, Hopital Bichat Claude Bernard, \\ Assistance Publique Hopitaux de Paris and universite Paris VII Denis Diderot, Paris, France \\ ${ }^{4}$ Institute of Antimicrobial Chemotherapy, Smolensk State Medical Academy, Russia \\ ${ }^{5}$ Department of Surgery, Catholic University, Policlinico A. Gemelli, Rome, Italy
}

\begin{abstract}
Recently, an update of the IDSA guidelines for the treatment of complicated intraabdominal infections has been published. No guideline can cater for all variations in ecology, antimicrobial resistance patterns, patient characteristics and presentation, health care and reimbursement systems in many different countries. In the short time the IDSA guidelines have been available, a number of practical clinical issues have been raised by physicians regarding interpretation of the guidelines. The main debatable issues of the new IDSA guidelines are described as follows:

The authors of the IDSA guidelines present recommendations for the following subgroups of ,complicated“ IAI: community-acquired intra-abdominal infections of mild-to-moderate and high severity and health care-associated intra-abdominal infections (no general treatment recommendations, only information about antimicrobial therapy of specific resistant bacterial isolates). From a clinical point of view, „complicated" IAI are better differentiated into primary, secondary (community-acquired and postoperative) and tertiary peritonitis. Those are the clinical presentations of IAI as seen in the emergency room, the general ward and on ICU. Future antibiotic treatment studies of IAI would be more clinically relevant if they included patients in studies for the efficacy and safety of antibiotics for the treatment of the above mentioned forms of IAI, rather than conducting studies based on the vague term „,complicated“ intra-abdominal infections.

The new IDSA guidelines for the treatment of resistant bacteria fail to mention many of new available drugs, although clinical data for the treatment of „complicated IAI“ with new substances exist. Furthermore, treatment recommendations for cIAI caused by VRE are not included. This group of diseases comprises enough patients (i.e. the entire group of postoperative and tertiary peritonitis, recurrent interventions
\end{abstract}

in bile duct surgery or necrotizing pancreatitis) to provide specific recommendations for such antimicrobial treatment.

A panel of European colleagues from surgery, intensive care, clinical microbiology and infectious diseases has developed recommendations based on the above mentioned clinical entities with the aim of providing clear therapeutic recommendations for specific clinical diagnoses. An individual patient-centered approach for this very important group of diseases with a substantial morbidity and mortality is essential for optimal antimicrobial treatment.

\section{PREFACE}

Recently, an update of the IDSA guidelines for the treatment of complicated intraabdominal infections has been published [1]. This comprehensive document has been thoroughly collated by reknown experts in the field and its influence extends well beyond the USA, making it a worldwide gold standard immediately after publication. However, it is a guideline, and no guideline can cater for all variations in ecology, antimicrobial resistance patterns, patient characteristics and presentation, health care and reimbursement systems in many different countries. In the short time the guidelines have been used clinically, several areas of confusion have arisen and been identified. Following such observations and personal experiences, a panel of European colleagues from surgery, intensive care, clinical microbiology and infectious diseases met several times to discuss the problematic issues associated with the new IDSA guidelines.

The following recommendations and observations on a very important group of diseases with a substantial morbidity and mortality are not meant to stand in contradict to the IDSA guidelines, but rather to add some information and guidance for the management of complicated intra-abdominal infections where the 
authors believe it could be of value for clinicians treating those patients. The main contentious issues in the recent IDSA guidelines are as follows:

\section{ISSUE 1 - DEFINITIONS}

The IDSA defines complicated and uncomplicated intra-abdominal infections. In complicated intra-abdominal infections the infection extends beyond the hollow viscus of origin into the peritoneal space and is associated with either abscess formation or peritonitis, whereas an uncomplicated infection involves intramural inflammation of the gastrointestinal tract [1].

This appears to be an artificial differentiation which does not always translate into clinical reality. For instance, a patient with an appendicitis with a tip of fibrin on top of the appendix (assumed mortality: 0.5$2 \%$ ) has a „complicated“ IAI according to these definitions whereas a Clostridium difficile-associated colitis with PCR-ribotype 027 (mean mortality: 20-30\%) is an „uncomplicated“ IAI following the IDSA criteria. A complicated IAI is defined best by its course and clinical severity and not necessarily by its local extent. Therefore, the above mentioned definition should be used with caution.

The authors of the IDSA guidelines present treatment recommendations for the following briefly defined subgroups of „complicated“ IAI: communityacquired intra-abdominal infections of mild-to-moderate and high severity and health care-associated intraabdominal infections. There are no general empirical treatment recommendations, only information on antimicrobial therapy of specific resistant bacteria.

From a clinical point of view, „complicated“ IAI are better differentiated into primary, secondary (community-acquired and postoperative) and tertiary peritonitis [2]. Those are the clinical presentations of IAI as seen in the emergency room, the general ward and on ICU. In recently published manuscripts dealing with critical conditions in IAI the authors have referred to the above mentioned definitions [3, 4]. Therefore, it is much closer to clinical conditions if guidelines follow this classification. The panel believes that further studies on antimicrobial agents in IAI should not longer refer to „complicated“ and ,uncomplicated" as this leads to a mixture of very different clinical entities and therefore may weaken the value of these studies. It would be more accurate in future to include patients in studies for the efficacy and safety of antibiotics for the treatment of community-acquired secondary peritonitis, postoperative secondary peritonitis and tertiary peritonitis, respectively, rather than to conduct studies based on the vague term „complicated“ intra-abdominal infections.

\section{Issue 2 - RESISTANT BACTERIA, ANTIBIOTIC Diversity AND ANTIBIOTIC STEWARDShiP}

Due to the substantially increasing, but geographically varying prevalence of resistant Gram-positive and Gram-negative pathogens there have been numerous efforts to encourage research in the development of new antimicrobials with efficacy and safety in this field [5]. As a result, new antibiotics with efficacy against re- sistant bacteria (linezolid against MRSA and VRE, daptomycin against MRSA and VRE, tigecycline against MRSA, VRE, ESBL-producing Enterobacteriaceae, Carbapenem-resistant bacteria) have shown activity in vitro and in vivo $[6,7,8]$. Unfortunately, the new IDSA guidelines for the treatment of resistant bacteria summarized in a table about treatment of ,health-care associated complicated intra-abdominal infection" fail to mention any of these drugs [1], although clinical data for the treatment of „,complicated IAI“ exist for linezolid and tigecycline which is approved for „cIAI“ [8$10,11^{*}, 12^{*}(*=$ published after the IDSA guidelines have been published)]. Certainly, the clinical data for all of the mentioned drugs in ,cIAI“ are weak and concerns about an increased mortality rate under tigecycline treatment remain (for „cIAI“ the mortality rate was $0.7 \%$ (non-significantly) higher in the tigecycline group than in the comparator group) $[8,13]$. However, randomized double blind trials for the efficacy and safety of an antibiotic in the treatment of "cIAI“" caused by resistant organisms such as MRSA, VRE or ESBL-producing Enterobacteriaceae are unlikely to be carried out. Consequently, as long as more than one therapeutic alternative is available, the application of antibiotic diversity appears to be a very useful tool in order to reduce the antibiotic selective pressure on any substance as a part of an antibiotic stewardship program [14-17]. It is inappropriate to restrict treatment recommendations for MRSA in cIAI to vancomycin and for ESBL-producing Enterobacteriaceae to carbapenems and piperacillin/tazobactam [1]. A recommendation that includes the existing variety of antibiotics with clinical data from the treatment in IAI (vancomycin, linezolid and tigecycline for MRSA, linezolid and tigecycline for VRE, carbapenems, piperacillin/ tazobactam, tigecycline and colistin for ESBL, see Table 5) provides a choice between substances in terms of an individual approach to every patient with minimization of toxicity and resistance development.

\section{ISSUE 3 - VRE, CARBAPENEMASE-PRODUCING Pathogens, ACINETobacter spP.}

The new IDSA guidelines do not include any treatment recommendations for cIAI caused by VRE. The authors of the guideline describe only patients such as liver transplant recipients with an intra-abdominal infection originating in the hepatobiliary tract or patients known to be colonized with VRE as a risk factor. In fact, the value of the administration of an anti-enterococcal agent for the prognosis of patients with IAI is discussed controversial, but the entire group of postoperative and tertiary peritonitis, recurrent interventions in bile duct surgery, necrotizing pancreatitis, and those with valvular heart disease or prosthetic intravascular materials have a substantial risk (varying from country to country and from hospital to hospital) for involvement of VRE which is a risk factor for treatment failure and death. This group of diseases comprises enough patients to provide specific recommendations for such antimicrobial treatment. These are shown in Table 5, as well as recommendations for the treatment of Cabapenemase-producing bacteria and Acinetobacter spp. 


\section{IntRoduction AND TreatMent PRINCIPLES}

Intra abdominal infections (IAI) are common. $\mathrm{Na}$ tional and international databases show that one in four cases of severe sepsis or septic shock is caused by IAI. It is the second most common focus of septic shock after pulmonary causes [18-20]. Almost $90 \%$ of all intra abdominal infections are so called secondary peritoneal infections and require primarily a surgical approach (i.e. appendectomy for a perforated appendicitis). There is overwhelming evidence for antibiotic treatment compared to placebo in this disease group [21]. However, primary inadequate and inappropriate antibiotic regimens have a substantially worse prognostic outcome for patients with IAI and cause substantial increase in health care costs [2224].

Recommendations for the empirical antibiotic treatment of IAI are based on a multitude of prospective randomized and controlled studies. Complicated IAI, by definition, are not necessarily a severe disease. In trials designed for showing equivalence of antibiotics or used for registration of new antibiotics the 'usual' intra-abdominal infections enrolled are associated with an APACHE II score between 4 and 6. Aiming to show a therapeutic equivalence, even the results of a recent Cochrane analysis were not able to demonstrate superiority of any particular antibiotic or treatment scheme [21].

In this manuscript every antibiotic / group of antibiotics is provided with a specific level of evidence and strength of recommendation shown which is modified after $[25,26]$ and shown in Table 1 . The level of evidence follows the quality of studies for the specific drug, the strength of recommendation takes considerations of toxicity and potential for development of resistance into account.

Choosing the right antibiotics for a particular patient should be influenced by a multitude of factors, i.e. patients (co-morbidities, immuno-suppression, previous antimicrobial treatment), expected microbial spectrum, local bacterial and resistance statistics, ease of application, level of toxicity and costs.

In recent years the evaluation of antibiotic treatment schemes were improved through differentiating peritonitis subgroups. These guidelines follow the clinical definitions of primary, secondary and tertiary peritonitis (Tables 2-4), based on [35]. Increasing

Table 1. Levels of evidence and strength of recommendation modified after [25, 26].

\begin{tabular}{l|l}
\hline $\begin{array}{l}\text { Level of evidence } \\
1\end{array}$ & $\begin{array}{l}\text { Explanation } \\
\text { Meta-analysis of randomized controlled trials, good quality randomized controlled trials or 'all } \\
\text { or none' studies in which no treatment is not an option } \\
\text { 'Low quality' randomized controlled trials (<80\% follow up), meta-analysis of good quality } \\
\text { prospective 'cohort studies' or well designed controlled study without randomization } \\
\text { Good quality retrospective 'case-control'-studies or comparative studies } \\
\text { Consensus, usual practise, disease-oriented evidence, and/or expert opinion }\end{array}$ \\
3 & $\begin{array}{l}\text { Explanation } \\
\text { Use of agent is recommended ("do it") } \\
\text { A }\end{array}$ \\
B & $\begin{array}{l}\text { Use of agent should be considered ("probably do it") } \\
\text { C }\end{array}$ \\
\hline
\end{tabular}

Table 2. Recommendations for initial therapy of primary and CAPD-associated peritonitis. $*=$ use antibiotic only if local susceptibility rates are $\geq 90 \%$.

\begin{tabular}{|c|c|c|c|c|}
\hline Diagnosis & Likely organisms & Initial therapy & Level of evidence & $\begin{array}{l}\text { Strength of } \\
\text { recommenddation }\end{array}$ \\
\hline $\begin{array}{l}\text { Spontaneous bacterial } \\
\text { peritonitis } \\
\text { (mostly liver cirrhosis } \\
\text { associated) }\end{array}$ & $\begin{array}{l}\text { Escherichia coli } \\
\text { Enterococci } \\
\text { Klebsiella spp. }\end{array}$ & $\begin{array}{l}\text { Ceftriaxon } \\
\text { Acylaminopenicillin/BLI } \\
\text { Ciprofloxacin* } \\
\text { Levofloxacin* }\end{array}$ & $\begin{array}{l}3 \\
3 \\
3 \\
3\end{array}$ & $\begin{array}{l}\text { A } \\
\text { A } \\
\text { A } \\
\text { B }\end{array}$ \\
\hline $\begin{array}{l}\text { CAPD - associated } \\
\text { peritonitis }\end{array}$ & $\begin{array}{l}\text { S. aureus } \\
\text { Enterococci } \\
\text { Other Streptococci } \\
\text { Escherichia coli } \\
\text { Enterobacteriaceae } \\
\text { Pseudomonas } \\
\text { Acinetobacter } \\
\text { MRSA, VRE } \\
\text { ESBL } \\
\text { Candida sp. }\end{array}$ & $\begin{array}{l}\text { Cephalosporin group } 2 \\
\text { with/without } \\
\text { Ciprofloxacin* } \\
\text { Vancomycin + Gentamicin } \\
\text { See Table } 5 \\
\text { See Table } 5 \\
\text { See Table } 6\end{array}$ & 3 & A \\
\hline
\end{tabular}


Table 3. Recommendations for initial therapy of different forms of secondary peritonitis. BLI=Beta-lactamase inhibitor, MRSA=Methicillin resistant S. aureus, VRE $=$ Vancomycin-resistant Enterococcus spp., ESBL $=$ extended spectrum beta-lactamase producing species, met. $=$ metronidazole,$+=$ Combination with antibiotics covering gram negative and anaerobic species required, $\#=$ Combination with Pseudomonas-active antibiotics required if Pseudomonas is suspected; $*=$ use antibiotic only if local susceptibility rates are $\geq 90 \%$.

\begin{tabular}{|c|c|c|c|c|}
\hline Diagnosis & Likely organism & Initial therapy & Level of evidence & $\begin{array}{l}\text { Strength of } \\
\text { recommendation }\end{array}$ \\
\hline $\begin{array}{l}\text { Community-acquired } \\
\text { localized peritonitis } \\
\text { (e.g. recently perforated } \\
\text { appendicitis) }\end{array}$ & $\begin{array}{l}\text { Enterobacteriaceae } \\
\text { Enterococci } \\
\text { Anaerobes }\end{array}$ & $\begin{array}{l}\text { Cephalosporin group } 2 / 3 \mathrm{a} \\
+ \text { metronidazole } \\
\text { Aminopenicillin/BLI } \\
\text { Acylaminopenicillin/BLI } \\
\text { Ciprofloxacin* + Met. }\end{array}$ & $\begin{array}{l}1 / 1 \\
1 \\
1 \\
1\end{array}$ & $\begin{array}{l}\mathrm{A} / \mathrm{A} \\
\mathrm{A} \\
\mathrm{A} \\
\mathrm{B}\end{array}$ \\
\hline $\begin{array}{l}\text { Community-acquired } \\
\text { diffuse peritonitis } \\
\text { +- risk factors } \\
\text { (e.g. perforated colonic } \\
\text { carcinoma) }\end{array}$ & $\begin{array}{l}\text { Enterobacteriaceae } \\
\text { Enterococci } \\
\text { Anaerobes }\end{array}$ & $\begin{array}{l}\text { Cephalosporin group } 3 \mathrm{a}+ \\
\text { metronidazole } \\
\text { Acylaminopenicillin/BLI } \\
\text { Imipenem-Cilastatin } \\
\text { Meropenem } \\
\text { Doripenem } \\
\text { Ertapenem } \\
\text { Moxifloxacin } \\
\text { Tigecycline } \\
\text { Cefepime } \\
\text { Ciprofloxacin*+ Met. } \\
\text { Levofloxacin* + Met. }\end{array}$ & $\begin{array}{l}1 \\
1 \\
1 \\
1 \\
1 \\
1 \\
1 \\
1 \\
1 \\
1 \\
1\end{array}$ & $\begin{array}{l}\text { A } \\
\text { A } \\
\text { A } \\
\text { A } \\
\text { A } \\
\text { A } \\
\text { A } \\
\text { B } \\
\text { B } \\
\text { B } \\
\text { B }\end{array}$ \\
\hline $\begin{array}{l}\text { Nosocomial } \\
\text { postoperative, post- } \\
\text { traumatic or post- } \\
\text { interventional diffuse } \\
\text { peritonitis } \\
\text { (e.g. anastomotic } \\
\text { leakage following } \\
\text { ileotransversostomy) }\end{array}$ & $\begin{array}{l}\text { Enterobacteriaceae } \\
\text { Enterococci } \\
\text { Anaerobes } \\
\text { Staphylococci } \\
\\
\text { MRSA } \\
\text { VRE } \\
\text { ESBL } \\
\text { Candida spp. }\end{array}$ & $\begin{array}{l}\text { Imipenem-Cilastatin } \\
\text { Meropenem } \\
\text { Doripenem } \\
\text { Acylaminopenicillin/BLI } \\
\text { Ertapenem\# } \\
\text { Tigecycline\# } \\
\text { Moxifloxacin } \\
\text { see Table } 5 \\
\text { see Table } 6\end{array}$ & $\begin{array}{l}1 \\
1 \\
1 \\
1 \\
1 \\
2 \\
1\end{array}$ & $\begin{array}{l}\text { A } \\
\text { A } \\
\text { A } \\
\text { A } \\
\text { A } \\
\text { A } \\
\text { B }\end{array}$ \\
\hline
\end{tabular}

Table 4. Recommendations for the initial therapy of tertiary peritonitis. \#= combination therapy with pseudomonas-active agent required if Pseudomonas is suspected

\begin{tabular}{|c|c|c|c|c|}
\hline Diagnosis & Likely organism & Initial therapy & Level of evidence & $\begin{array}{l}\text { Strength of } \\
\text { recommendation }\end{array}$ \\
\hline $\begin{array}{l}\text { Persisting peritonitis } \\
\text { despite adequate } \\
\text { surgical and initial } \\
\text { antimicrobial therapy }\end{array}$ & $\begin{array}{l}\text { Enterobacteriaceae } \\
\text { (Enterococci) } \\
\text { (Staphylococci) } \\
\text { Anaerobes } \\
\text { MRSA, VRE } \\
\text { ESBL } \\
\text { Pseudomonas spp. } \\
\text { Candida spp. }\end{array}$ & $\begin{array}{l}\text { Imipenem-Cilastatin } \\
\text { Meropenem } \\
\text { Acylaminopenicillin/BLI } \\
\text { Tigecycline\# } \\
\text { Ertapenem\# } \\
\text { Ceftriaxone+ } \\
\text { Metronidazole } \\
\text { see Table } 5 \\
\text { see Table } 6\end{array}$ & $\begin{array}{l}2 \\
2 \\
2 \\
2 \\
4 \\
4\end{array}$ & $\begin{array}{l}\text { A } \\
\text { A } \\
\text { A } \\
\text { A } \\
\text { B } \\
\text { B }\end{array}$ \\
\hline
\end{tabular}

numbers of IAI caused by multi-resistant agents (MRSA, VRE, ESBL-producing Enterobacteriaceae) or difficult treatable species (i.e. Pseudomonas, Candi$d a)$ were accommodated by extra data (Tables 5,6 ). 
Table 5. Calculated and targeted antibiotic therapy with suspected or proven IAI with multi-resistant agents $($ MRSA=Methicillin resistant S. aureus, VRE $=$ Vancomycin-resistant Enterococcus spp., ESBL $=$ extended spectrum beta-lactamase producing species, $+=$ Combination with antibiotics covering gram negative and anaerobic species required, \# $=$ Combination with Pseudomonas-active antibiotics required if Pseudomonas is suspected; $\diamond=$ no monotherapy, $*=$ use antibiotic only if local susceptibility rates are $\geq 90 \%$.

\begin{tabular}{|c|c|c|c|}
\hline Agent & Antibiotic & Level of evidence & Strength of recommendation \\
\hline MRSA & $\begin{array}{l}\text { Tigecycline\# } \\
\text { Linezolid+ } \\
\text { Daptomycin+ } \\
\text { Vancomycin+ } \\
\text { Cotrimoxazole+ }\end{array}$ & $\begin{array}{l}2 \\
3 \\
4 \\
4 \\
4\end{array}$ & $\begin{array}{l}\text { A } \\
\text { A } \\
\text { C } \\
\text { B } \\
\text { C }\end{array}$ \\
\hline VRE & $\begin{array}{l}\text { Tigecycline\# } \\
\text { Linezolid+ }\end{array}$ & $\begin{array}{l}2 \\
3\end{array}$ & $\begin{array}{l}\text { A } \\
\text { A }\end{array}$ \\
\hline $\begin{array}{l}\text { ESBL-producing } \\
\text { (E. coli, Klebsiella spp.) }\end{array}$ & $\begin{array}{l}\text { Imipenem } \\
\text { Meropenem } \\
\text { Doripenem } \\
\text { Ertapenem\# } \\
\text { Tigecycline\# } \\
\text { Acylaminopenicillin/BLI } \\
\text { Fosfomycin } \diamond\end{array}$ & $\begin{array}{l}3 \\
3 \\
3 \\
3 \\
2 \\
3 \\
4\end{array}$ & $\begin{array}{l}\text { A } \\
\text { A } \\
\text { A } \\
\text { A } \\
\text { A } \\
\text { A } \\
\text { B }\end{array}$ \\
\hline Pseudomonas spp. & $\begin{array}{l}\text { Imipenem } \\
\text { Meropenem } \\
\text { Doripenem } \\
\text { Acylaminopenicillin/BLI } \\
\text { Cefepim } \\
\text { Aminoglycoside } ~ \\
\text { Ciprofloxacin* } \\
\text { Levofloxacin* }\end{array}$ & $\begin{array}{l}4 \\
4 \\
4 \\
4 \\
4 \\
4 \\
4 \\
4\end{array}$ & $\begin{array}{l}\text { A } \\
\text { A } \\
\text { A } \\
\text { A } \\
\text { A } \\
\text { B } \\
\text { A } \\
\text { A }\end{array}$ \\
\hline Acinetobacter spp. & $\begin{array}{l}\text { Colistin } \\
\text { Tigecycline\# }\end{array}$ & $\begin{array}{l}2 \\
4\end{array}$ & $\begin{array}{l}\text { A } \\
\text { A }\end{array}$ \\
\hline $\begin{array}{l}\text { Carbapenemase- } \\
\text { producing species } \\
\text { (i.e. KPC) }\end{array}$ & $\begin{array}{l}\text { Tigecycline\# } \\
\text { Colistin }\end{array}$ & $\begin{array}{l}4 \\
4\end{array}$ & $\begin{array}{l}\text { A } \\
\text { B }\end{array}$ \\
\hline
\end{tabular}

Table 6. Treatment strategy with suspected or proven invasive intra-abdominal mycotic infection with Candida spp.

\begin{tabular}{|c|c|c|c|}
\hline Diagnosis & Initial therapy & Level of evidence & Strength of recommendation \\
\hline Colonization with Candida spp. & none & 3 & A \\
\hline $\begin{array}{l}\text { Suspected or proven invasive } \\
\text { mycosis: stable patient }\end{array}$ & $\begin{array}{l}\text { Fluconazole } \\
\text { Voriconazole }\end{array}$ & $\begin{array}{l}3 \\
4\end{array}$ & $\begin{array}{l}\text { A } \\
\text { B }\end{array}$ \\
\hline $\begin{array}{l}\text { Suspected or proven invasive } \\
\text { mycosis: instable patient }\end{array}$ & $\begin{array}{l}\text { Echinocandin } \\
\text { (Anidulafungin, } \\
\text { Caspofungin, Micafungin) } \\
\text { If Candida spp. is } \\
\text { fluconazole-susceptible, } \\
\text { Step-down therapy to } \\
\text { Fluconazole or } \\
\text { Voriconazole }\end{array}$ & $\begin{array}{l}3 \\
3\end{array}$ & $\begin{array}{l}\text { A } \\
\\
\text { A } \\
\text { A }\end{array}$ \\
\hline
\end{tabular}

There are no reliable data yet regarding treatment duration of IAI. The following recommendations are based on therapy intervals stated in randomised studies, diagnostic characteristics of certain infectious agents (i.e. Candida sp.), whether the infection is local or systemic, as well as the author's experience. Whenever the patient is improving clinically and inflammatory signs decreasing, the antibiotic discontinuation should be considered, especially to prevent pathogen selection and undesirable side effects. Has a treatment success, even in severe infections, not occurred after 7 days, the treatment discontinuation should be considered in favour of repeated culture sampling, especially to prevent selection of multi-resistant pathogens and possible toxic side effects. Additional imaging procedures, search of other foci of infection, need of sub- 
sequent re-operations are other issues to address in this setting.

Peritonitis as the most frequent form of IAI constitutes a very complex reaction of the peritoneum and its histological structure to bacterial, viral, fungal or chemical stimuli. Three main forms of peritonitis can be differentiated according to its causative pathogenesis, its spectrum of pathogens and according to surgical and antimicrobial therapy [2]:

\section{PRIMARY PERITONITIS}

Primary (spontaneous bacterial) peritonitis (SBP) constitutes only about $1 \%$ of all peritonitis cases [27]. The juvenile form has its origin in a hematogenous spread infection, usually streptococci, pneumococci or very rarely Haemophilus influenzae. In adults in the majority of cases $(70 \%)$, SBP is associated with ascites and alcohol-associated liver cirrhosis or other causes of a reduced immune system (30\%). It is diagnosed when the ascites neutrophil count exceeds 250/ul [28]. In most cases, it constitutes a mono infection through translocation or hematogenous spreading. In studies portraying the clinical setting realistically, only in about $35 \%$ of cases the causative agent is isolated and then shared among E. coli, Klebsiella sp., staphylococci, enterococci or streptococci. The insufficient rate of bacterial detection is explained through the fact that in the clinical setting only about $50 \%$ of cases with SBP ascites is harvested for cultural testing [28].

Primary peritonitis in tuberculosis is usually caused by hematogenous spreading.

Randomised trials for SBP treatments are rare. Most of the studies are retrospective works that should be classified as treatment surveillance trials. The following recommendations thus do not support higher evidence levels (Table 2). Antibiotics used were ceftriaxone, cefotaxime, ceftazidime as well as acylaminopenicillins with anti-beta-lactamase activity [2831 . With these agents clinical cure rates of up to $83 \%$ were achieved.

\section{Peritonitis Associated with CAPD}

CAPD associated peritonitis is usually caused by tubeor catheter contamination. Most frequently involved causative agents are coagulase-negative staphylococci and Staphylococcus aureus. Other less frequent involved agents are E. coli, enterococci, other streptococci, Pseudomonas aeruginosa, anaerobes, Enterobacter spp., Acinetobacter sp., Proteus sp. or Candida species [32]. Uncomplicated cases can be treated successfully by adding antimicrobial agents to the dialysis fluid. Only in rare and serious cases antibiotics have to be given not only into the peritoneum but parenteral as well. In patients with renal failure applicated drugs have to be monitored and doses adjusted. The recommended empirical therapy is usually started with vancomycin plus gentamicin or a group 2 cephalosporin with or without ciprofloxacin [33]. The therapy should be then continued after bacteriology results have been obtained. In cases with proven MRSA-, MRSE- and Enterococcae (incl. VRE) infections, antibiotics in Table 4 should be applied. In cases with proven my- cotic CAPD-peritonitis, agents in Table 5 should be considered. If the infection is not controlled within 7 days, the peritoneal dialysis catheter must be removed and additional investigations performed in search for a reason of persistent infection.

\section{SECONDARY PERITONITIS}

Secondary peritonitis is caused by a gastrointestinal (GI) perforation and is with $80-90 \%$ by far the most frequent IAI. Per definition, a surgical intervention (i.e. appendectomy in perforated appendicitis) must follow. A primary surgical intervention with definitive abdominal closure and clinical surveillance has become the treatment of choice for most patients with secondary peritonitis [34]. Secondary peritonitis can be further differentiated into community acquired (about $70 \%$ of all SP) and postoperative (about 30\%).

\section{COMmunity ACQuired SECONDARY PERITONITIS}

Community acquired secondary peritonitis is always a mixed infection. Apart from surgical interventions aiming to repair the bacterial leakage, a calculated antibiotic therapy should always be initiated pre-operatively or intra-operatively. Its bacterial spectrum can differ depending on the site of the perforation or leakage. Most frequently involved bacteria are E. coli, Bacteroides fragilis and other anaerobes and enterococci.

Following gastro-duodenal perforations bacterial counts are usually low $\left(<10^{3} / \mathrm{ml}\right)$ and aerobic/anaerobic mixed infections rather rare. Perforations of the biliary system or jejunum usually produce intermediate bacterial counts $\left(10^{3}-10^{5}\right)$ and a mixed aerobic/ anaerobic infection in $50 \%$ of cases. Colon- or ileum perforations produce high bacterial counts $\left(>10^{5}\right)$ and almost always a mixed aerobic/anaerobic bacterial infection [35].

Localised acute peritoneal infections (i.e. acute appendicitis with existing peritoneal contamination of less than 6 hours) show usually a clear or cloudy exudate. Usually available antibiotics are aminopenicillin/BLI, acylaminopenicillin/BLI, ertapenem, alternatively group 2 cephalosporins in combination with metronidazole or ceftriaxone. Therapy duration can be reduced to 1-2 days in localized cases with a short $(<6$ hours) duration of peritoneal contamination (see Table 3). A two to four hours existing diffuse peritonitis, which could not be sufficiently controlled and showing a putrid and faecal exudate, should be treated with single agents or a combination of agents with broad spectrum activity. The empirical therapy should include acylaminopenicillin/BLI or group 1 (ertapenem) or group 2 (imipenem/cilastatin, meropenem, doripenem) carbapenems. Alternatively combinations of metronidazole with group 2 , $3 \mathrm{a}$ or 4 cephalosporins, ciprofloxacin, levofloxacin or a moxifloxacin monotherapy. Antibiotics covering the enterococci are usually not required in community acquired intra-abdominal infections. Antibiotic treatment of enterococci is recommended in postoperative IAI or seriously ill patients $[36,37]$. 
A Cochrane analysis for Beta lactam antibiotic monotherapy versus lactam-aminoglycoside antibiotic combination therapy for sepsis did not show any additional positive effects for aminoglycoside combination therapy [38]. Aminoglycosides still have their place in combination with broad spectrum sensitive Beta-lactam-inhibitors (especially Carbapenems, Acylaminopenicillin/BLI) for the treatment of Pseudomonas spp. [39, 40]. Variable kinetic parameters as well as oto- and nephrotoxicity require repeated serum-level controls.

\section{Postoperative Peritonitis}

Postoperative peritonitis is a nosocomial secondary peritonitis form and defined as an infectious abdominal complication following surgical interventions (i.e. anastomotic insufficiency following anterior rectum resection) [2]. Postoperative infections compared to tertiary peritoneal infections always require a surgical approach [36, 37, 41]. Because of diagnostic and therapeutic difficulties as well as worse prognostic factors, it has its own entity among secondary peritoneal infections [4]. The majority of patients are usually already covered by antibiotics when the diagnosis is made and the microbial causes of such peritonitis tend to be multiple drug-resistant (MDR) including enterococci (incl. VRE), Gram-negative organisms (ESBL or AmpC or carbapenemase-producer), MRSA and Candida species.

Thus the choice of antibiotics in these cases needs to be influenced by local epidemiology and susceptibility of isolates. Appropriate agents may be carbapenems, tigecycline, piperacillin/tazobactam or moxifloxacin depending on microbial findings (Table 3) Antifungal treatment is recommended for proven fungal infections (Table 6).

\section{TERTIARY PERITONITIS}

Tertiary peritonitis is a persistent intra-abdominal infection without a surgically treatable focus, following an earlier surgical intervention and source control [2]. In most cases the infection is maintained because of a state of immunodeficiency and or due to resistant bacteria selection following antibiotic treatments. Patients who might develop tertiary peritonitis are very difficult to identify. Compared to cases of secondary peritonitis there are significant higher MPI-score, SAPS II-score and elevated CRP-serum levels [41]. This form of nosocomial peritonitis shows a similar shifted bacterial spectrum which is also found in postoperative secondary peritonitis. Frequently found bacteria include enterococci (incl. VRE), staphylococci incl. MRSA, enterobacteriaceae, anaerobes and Candida species [36]. Compared to postoperative peritonitis, the tertiary form does not require any surgical intervention $[2,4]$ but this point is difficult to assess until a non-contributory surgical intervention proves that the patient has indeed a tertiary peritonitis. Antibiotics that may work in this subgroup of patients are either group 1 or 2 carbapenems, tigecycline (in combination with a Pseudomonas-active agent if a relevant pathogenetic role of Pseudomonas spp. is suspected or proven), acylaminopenicillin with Beta-lactam-inhibitor or group 3 a cephalosporins in combination with metronidazole (see Table 4) [36, 42]. Treatment recommendations for invasive fungal intra-abdominal infections are found in Table 6. Post-peritonitis abscess formations should be drained CT-guided and treated according to its antimicrobial spectrum.

\section{Difficult to Treat and Multi-Resistant BACTERIA}

During the mid nineties $95-97 \%$ of all IAI associated microbes were sensitive against commonly used antibiotics (Group 2a cephalosporins with metronidazole, ciprofloxacin) [43], in recent years the share of resistant species have increased worldwide [41, 44, 45]. Especially in postoperative and tertiary peritonitis as well as with antibiotics pretreated necrotising pancreatitis, one has to assume an involvement of resistant or difficult treatable bacteria (MRSA, VRE, ESBL-producer, Pseudomonas spp. Acinetobacter spp. and Carbapenemase-producing organisms) [12, 44, 45]. Individual risk-constellations can also exist, if prior to the intraabdominal infection, antibiotic treatments occurred (i.e. infected diabetic foot). In Table 5 there is a description of different species and treatment recommendations (Table 5).

\section{MRSA}

Intra-abdominal infections with MRSA in immunocompetent patients are very rare. In most cases MRSA-colonisation follows after leaving the abdomen open (i.e. intra-abdominal compartment syndrome). Non-compromised patients should receive antibiotic treatment, if they show local or systemic inflammatory signs or have a persistent high isolation count. All post-transplantation patients with iatrogenic induced immunodeficiency and evidence for MRSA (colonization or infection) should be treated. Tigecycline offers among the new anti-MRSA sensitive antibiotics a license for IAI [8] and also covers the expected Gramnegative and anaerobic spectrum. Recent clinical data for the treatment of MDR-caused complicated IAI with tigecycline showed clinical success rates between 75-80\% [10-12]. If Pseudomonas spp. are found or suspected to be relevant in causing the infection, a Pseudomonas-active agent has to be added. Linezolid and daptomycin are solely active against Gram-positive bacteria $[6,7,9]$. Compared to vancomycin, they offer a good tissue penetration. Clinical data for the treatment of IAI with linezolid are available [9]. Linezolid, daptomycin and vancomycin should be combined with antibiotics covering Gram-negative species, as intra-abdominal Gram-positive mono-infections are rare [36]. Data about community acquired MRSA-IAI are currently not available.

\section{ENTEROCOCCI INCLUDING VRE}

Enterococci are an increasing cause of nosocomial infections. The role of enterococci as the primary pathogen in multi-bacterial IAI is discussed controversially, especially as a body of evidence is showing suc- 
cessful surgical treatments of IAI with antibacterial treatments without enterococcal coverage $[36,37,46]$. Enterococci-covering antibiotics are recommended in patients with post-operative peritonitis, tertiary peritonitis, severe sepsis of abdominal origin and antibiotic pretreatment or endocarditis-prone patients (Peritonitis and heart valve replacement) [37]. In all these indications with previous antibiotic treatment, vancomycin-resistant enterococci are likely to be encountered with E. faecium having greater pathogenic properties than E. faecalis. With the exception of vancomycin, all previously mentioned antibiotics are effective against MRSA. Rare linezolid-resistant enterococcal strains have been described [47].

\section{ESBL-Producing Pathogens}

Recent years have shown a trend among Enterobacteriaceae species (especially E. coli, K. pneumoniae) towards developing broad beta-lactamase-resistance including group 3 and 4 Cephalosporins, which are hydrolysed by so called extended-spectrum beta-lactamases (ESBL). A special role for the transmission of ESBL-species seems to be the colonisation of the animal- and human GI tract [48]. There is a relatively high prevalence of ESBL-producing species in visceral surgical departments [49]. In ESBL-infections carbapenems and tigecycline are almost the only agents of choice. Infections with strains resistant to carbapenems, fluoroquinolones and tobramycin can only be treated with either tigecycline or colistin [39, 40]. There is an urgency for the development of effective new anti-Gram-negative agents.

\section{PSEUDOMONAS SPP., ACINETOBACTER SPP., CARBAPENEMASE-PRODUCING BACTERIA}

Pseudomonas species are detected in about $8 \%$ of all IAI, whereas the percentage of causative strains is likely to be much lower $[50,51]$. Basically group $3 \mathrm{~b}$ Cephalosporins, group 2-4 fluoroquinolones, carbapenems, piperacillin/tazobactam and aminoglycosides are available, with combinations of above recommended [52]. In the event that 4 or more usually available pseudomonas-active agents turn out to be ineffective (so called pan drug resistance (PDR)), colistin is available for treatment although the data regarding the treatment of PDR Pseudomonas infections are based on nosocomial pneumonia and sepsis but not explicitly for peritonitis [39, 40]. The same goes for carbapenemase-producing pathogens and Acinetobacter species, where tigecycline and colistin are the only treatment options.

Especially in infections caused by multi-resistant bacteria, it is of paramount importance to anticipate the spectrum of bacteria when initiating antimicrobial therapy. If bacterial identification data and susceptibility patterns are not showing any resistant pathogens, de-escalation should be performed.

\section{INTRA-ABDOMINAL FUNGAL INFECTIONS}

Most of the intra-abdominal fungal infections are caused by Candida species. The prevalences of Candi- da-detection and infections on ICU's have increased in the last 20 years. About $18 \%$ of all severe septic infections may be caused by Candida species and of those cases $25 \%$ are invasive intra-abdominal mycosis (IIM) [20]. Finding Candida species in swabs obtained intraoperatively seems to correlate with a higher lethality [53]. The fact that diagnosing IIM through means other than blood cultures is very difficult might explain a much higher prevalence. Proof of IIM is evidence for Candida spp. from intra-operatively harvested tissue and, with caution, the microscopic and cultural detection in aspirated ascites [54]. Sensitivity and specificity of serological testing methods have improved, but can not be relied on at present [55]. Detecting Candida species in tracheal secretions, urine culture or wound secretions are usually uncomplicated colonisations not warranting any treatment. The same is true for an intra-operatively harvested positive specimens with community acquired peritonitis (e.g. perforated stomach ulcer). If the patient is immuno-competent and stable, there is no requirement for antifungal therapy. Prognosis of IIM is much worse with delayed treatment [54, 55]. High-risk collectives from a surgical point of view include patients with severe postoperative peritonitis (e.g. anastomotic leakage following esophagojejunostomy), missed perforations (i.e. Boerhaave-syndrome) and patients with abdominal sepsis with multiple tissue Candida-infestation (i.e. positive urine culture and wound secretion) [54-56]. In two studies pre-emptive treatment with fluconazole significantly reduced invasive fungal infections but failed to reduce overall mortality compared to placebo $[57,58]$. Nevertheless, the value of preemptive antifungal treatment is discussed controversial [53-55].

Once IIM is suspected or proven, different antifungals can be chosen from (see Table 6). A high-dosetherapy with fluconazole is sufficient for fluconazolesusceptible strains, but resistance of Candida spp. against fluconazole is increasing [59]. The IDSA guidelines for the treatment of invasive candidiasis recommend, that patients, who are either instable or have recently been given an azole therapy or prophylaxis, should initially receive an Echinocandin (anidulafungin, caspofungin, micafungin) [60]. If the isolated Candida spp. is fluconazole-susceptible, a step-down therapy to fluconazole should be performed.

Because of its toxicity, amphotericin B is only recommended as primary therapy in cases of proven allergic reactions toward other antifungals [60]. Currently a 14 day treatment period is regarded as sufficient, as long as the clinical and haematological results are improving [60]. Finally it should be noted, that an invasive intra-abdominal fungal infection can either be a classic case of tertiary peritonitis, or a secondary peritonitis with insufficient surgical source control [59]. In the last case a surgical intervention with successful source control is the prerequisite for a successful antifungal treatment.

\section{Necrotising Pancreatitis with Infected NECROSIS}

The severity of acute pancreatitis is measured by the presence or absence of distant organ failure, local 
complications or both [61]. Thus it would be important to identify patients who are expected to develop serious complications, as these would require intensive monitoring as well as possible surgical intervention. Pancreatic necroses constitute a clinically relevant complication, which can develop within the first few days of illness. Diagnosis is usually done through CT scanning. Necrosis is associated with late complications (corrosive haemorrhages, organ perforations) and increased lethality when they become infected. About $80 \%$ of all pancreatitis associated deaths are caused by septic complications. The translocation of colonic bacteria into the peripancreatic tissue is the most frequent cause of superinfected pancreatic necroses. Infected pancreatic necroses can be suspected, if (usually from week two of illness) patients develop fever, leukocytosis, elevated CRP-serum levels and an acute unexpected clinical deterioration. The visualisation of air bubbles within necrotic tissue on CT scans is highly suggestive of infection. In these and uncertain cases, an ultrasound- or CT-guided fine needle aspiration should be obtained and sent for laboratory testing (Gram-staining, microbiology), which could influence therapeutic strategy in patients already treated with antibiotics [62].

The treatments available for infected pancreatic necroses are either conservative measures (endoscopically guided transgastral drainage, CT-guided drainage) or surgical measures. A surgical intervention (open or minimally invasive) is usually best performed after 2 weeks into the disease process, as earlier surgical interventions carry higher mortality risks [63].

Until recently, prophylactic administration of antibiotics in necrotising pancreatitis was recommended [64]. New scientific data have shown, that prophylactic antibiotic treatments have no positive influence on the course of illness $[65,66]$. It is currently not recommended to initiate antibiotic treatment in necrotizing pancreatitis without infection [65-67]. A clear indication for antibacterial treatment is in all cases with proven infected necroses, infected pseudo cysts, abscess formation, cholangitis and other extra-pancreatic infections. The most important bacteria involved in infected pancreatic necroses are Enterobacteriaceae, Enterococci, Staphylococci, Anaerobes and Candida species. When choosing the appropriate antibiotic, it is important not only to think about the spectrum but also about adequate pancreatic tissue penetration. Studies with reliable data for adequate tissue penetration exist for quinolones (ciprofloxacin, moxifloxacin), carbapenems (imipenem/cilastatin, meropenem, ertapenem, doripenem), metronidazole, cephalosporins (cefotaxime, ceftazidime, cefepim) and penicillins (mezlocillin, piperacillin/tazobactam). Insufficient tissue penetration is shown for aminoglycosides [24]. Possible antibiotic therapy regimes are found in Table 7 . In suspected or proven infections with resistant species

Table 7. Calculated antibiotic therapy with necrotising pancreatitis and secondary cholangitis. (BLI= Beta-lactamase inhibitors, met.=Metronidazole, MRSA $=$ Methicillin resistant S. aureus, VRE $=$ Vancomycin-resistant Enterococcus spp., ESBL $=$ extended spectrum beta-lactamase producing species, \#= Combination with Pseudomonas-active antibiotics required if Pseudomonas is suspected; $*=$ use antibiotic only if local susceptibility rates are $\geq 90 \%$.

\begin{tabular}{|c|c|c|c|c|}
\hline Diagnosis & Likely organism & Initial therapy & Level of evidence & $\begin{array}{l}\text { Strength of } \\
\text { recommendation }\end{array}$ \\
\hline $\begin{array}{l}\text { Necrotizing pancreatitis } \\
\text { without infection }\end{array}$ & none & none & 1 & A \\
\hline $\begin{array}{l}\text { Necrotizing pancreatitis } \\
\text { with infected necrosis }\end{array}$ & $\begin{array}{l}\text { Enterobacteriaceae } \\
\text { Enterococci } \\
\text { Staphylococci } \\
\text { MRSA } \\
\text { VRE } \\
\text { ESBL } \\
\text { Candida spp. }\end{array}$ & $\begin{array}{l}\text { Imipenem-Cilastatin } \\
\text { Meropenem } \\
\text { Ertapenem\# } \\
\text { Acylaminopenicillin/BLI } \\
\text { Ciprofloxacin* + Met. } \\
\text { Levofloxacin* + Met. } \\
\text { Cephalosporin group } 2 \\
\text { + Metronidazole } \\
\text { see Table } 5 \\
\text { see Table } 6\end{array}$ & $\begin{array}{l}1 \\
1 \\
1 \\
1 \\
1 \\
1 \\
1\end{array}$ & $\begin{array}{l}\text { A } \\
\text { A } \\
\text { A } \\
\text { A } \\
\text { B } \\
\text { B } \\
\text { B }\end{array}$ \\
\hline Secondary cholangitis & $\begin{array}{l}\text { Enterobacteriaceae } \\
\text { Enterococci } \\
\text { Anaerobes } \\
\text { Pseudomonas spp. }\end{array}$ & $\begin{array}{l}\text { Aminopenicillin/BLI } \\
\text { Ciprofloxacin* + Met. } \\
\text { Levofloxacin* + Met. } \\
\text { Acylaminopenicillin/BLI } \\
\text { Ceftriaxon } \\
\text { Imipenem-Cilastatin } \\
\text { Meropenem } \\
\text { Ertapenem\# } \\
\text { Cefepime } \\
\text { See Table } 5\end{array}$ & $\begin{array}{l}1 \\
1 \\
1 \\
1 \\
1 \\
1 \\
1 \\
1 \\
3\end{array}$ & $\begin{array}{l}\text { A } \\
\text { B } \\
\text { B } \\
\text { A } \\
\text { B } \\
\text { A } \\
\text { A } \\
\text { A } \\
\text { B }\end{array}$ \\
\hline
\end{tabular}


(i.e. MRSA, VRE, ESBL), recommendations for resistant bacteria are shown in Table 5, for fungal infections in Table 6.

\section{SECONDARY CHOLANGITIS}

Infection of the biliary ductal system is usually caused by biliary obstruction. Causes are usually gallstones, benign structures and rarely tumorous obstructions (usually sterile). With the increase of obstruction, the probability of cholangitis raises with the possibility of systemic bacteremia. A positive bile duct culture is found in about 75 to $100 \%$ in biliary obstruction. The bacterial spectrum includes Enterobacteriacea, Enterococci and Anaerobes. In postoperative bacteremia, cholangiogenic sepsis, subhepatic abscesses and interventional approaches (ERCP or endoscopic papillotomy), other Gram-negative bacilli and Pseudomonas are encountered.

Primary therapy for choledocholithiasis is clearing the biliary system via ERC with consecutive laparoscopic cholecystectomy (so called therapeutic splitting). Obstructive cholangitis secondary to gallstones, should even in septic conditions be treated by endoscopic removal of stones. Inoperable tumours can also be successfully treated with stent-implants. A calculated antibiotic therapy can be started with either Aminopenicillin/BLI, Acylaminopenicillin/BLI or a group 3 or 4 Cephalosporin in combination with Metronidazole. Alternatively group 1 or 2 Carbapenems or group 2 or 3 Fluoroquinolones are administrated (Table 7). If Psendomonas spp. is involved or suspected, a relevant Pseudomonas-sensitive substance should be added [35].

\section{Clostridium-Difficile Associated Colitis}

Metronidazole and vancomycin are the agents of choice for the treatment of Clostridium difficile infection (CDI). Initial cure rates of $>90 \%$ have been reported. Fulminant or complicated severe CDI and recurrent CDI are matters of concern. Recommendations for the treatment of clostridium difficile infections have recently been published by [69].

Transparency declarations: CE has received speaker honoraria from Pfizer, Wyeth, Bayer, MSD and Novartis and has particpated on advisory boards for Wyeth and Pfizer. MD has received speaker honoraria and served on advisory boards for Pfizer, Wyeth, Bayer, Janssen-Cilag, Novartis. PM has received speaker honoraria and has participated on advisory boards for Astra Zeneca, Janssen Cilag, MSD and Pfizer. RK declares no conflict of interest. GS has receiverd speaker honoraria and has participated on advisory boards for Pfizer.

\section{REFERENCES}

1. Solomkin JS, Mazuski JE, Bradley JS et al. Diagnosis and management of complicated intra-abdominal infections in adults and children: guidelines by the Surgical Infection Society and the Infectious Diseases Society of America. Clin Inf Dis 2010;50:133-64

2. Weigelt JA. Empiric treatment options in the management of complicated intra-abdominal infections. Cleve Clin J Med 2007;74(suppl 4):S29-37

3. Augustin P, Kermarrec N, Muller-Serieys C, Montravers
P. Risk factors for multi-drug resistant bacteria and optimization of empirical antibiotic therapy in postoperative peritonitis. Crit Care 2010;14:R20

4. Bader F, Schroeder M, Kujath P, Muhl E, Bruch HP, Eckmann C. Diffuse prostoperative peritonitis:value of diagnostic parameters and impact of early indication for relaparotomy. Eur J Med Res 2009;14:1-6

5. Boucher HW, Talbot GH, Bradley JS et al. Bad bugs, no drugs: no ESKAPE! An update from the Infectious Diseases Society of America. Clin Inf Dis 2009;48:1-12

6. Itani KMF, Dryden MS, Bhattacharyya H, Kunkel MJ et al. Efficacy and safety of linezolid versus vancomycin for the treatment of complicated skin and soft-tissue infections proven to be caused by methicillin-resistant Staphylococcus aureus. Am J Surg 2010;

7. Arbeit RD, Maki D et al. The safety and efficacy of daptomycin for the treatment of complicated skin and skinstructure infections. Clin Inf Dis 2004; 38: 1673-1681

8. Babincak T, Ellis-Grosse E, Dartois $\mathrm{N}$ et al. The efficacy and safety of tigecycline for the treatment of complicated intra-abdominal infections. Clin INf Dis 2005;41:354-67

9. Birmingham MC, Rayner CR, Meagher AM et al. Linezolid in the treatment of multidrug-resistant, Gram-positive infections: experience from a compassionate-use program. Clin Inf Dis 2003;36:159-68

10. Swoboda S, Ober M, Hainer C et al. Tigecycline for the treatment of patients with severe sepsis or septic shock: a drug evaluation in a surgical intensive care unit. J Antimicrob Chemother 2008;61:729-33

11. Bassetti M, Nicolini L, Repetto E, Rghi E, Del Bono V, Viscoli C. Tigecycline use in serious nosocomial infections: a drug use evaluation. BMC Infect Dis 2010;10:287

12. Eckmann C, Heizmann WR, von Eiff C, Leitner E, Löschmann PA, Bodmann KF. Prospective, non-interventional multicentre trial of tigecycline in the treatment of severely ill patients. Chemother J 2010;19:165-166

13. http://www.fda.gov/Drugs/DrugSafety/ucm224370.htm (last visit Jan 15th 2011)

14. Dryden M. Complicated skin and soft tissue infection. J Antimicrob Chemother. 2010;65 (S3):iii35-44

15. Wilcox MH. The tide of antimicrobial resistance and selection. Int J Antimicrob Agents 2009; 34 S3: S6-10.

16. Nathwani D. New antibiotics for the management of complicated skin and soft tissue infections: are they any better? Int J Antimicrob Agents 2009; 34: S24-9.

17. Eckmann C, Dryden M. Treatment of complicated skin and soft-tissue infections caused by resistant bacteria: value of linezolid, tigecycline, daptomycin and vancomycin. Eur J Med Res 2010;15:554-563

18. Kumar A, Roberts D, Wood KE et al. Duration of hypotension before initiation of effective antimicrobial therapy is the critical determinant of survival in human septic shock. Crit Care Med 2006; 34: 1589-1596

19. Kumar A, Ellis P, Arabi Y et al. Initiation of inappropriate antimicrobial therapy results in a fivefold reduction of survival in human septic shock. Chest 2009;136:1237-48

20. Engel C, Brunkhorst FM, Bone HG et al. Epidemiology of sepsis in Germany: results from a national prospective multicenter study. Intensive Care Med 2007; 33: 606-618

21. Wong PF, Gilliam AD, Kumar S et al. Antibiotic regimens for secondary peritonitis of gastrointestinal origin in adults. Cochrane Database Syst Rev 2005; 18: CD004539

22. Edelsberg J, Berger A, Schell S et al. Economic consequences of failure of initial antibiotic therapy in hospitalized adults with complicated intra-abdominal infections. Surg Infect 2008; 9: 335-347

23. Barie P. The cost of failure. Surg Infect 2008; 9: 313-315

24. Davey PG, Marwick C. Appropriate versus inappropriate antimicrobial therapy. Clin Microbiol Infect 2008; 14S3: S15-S21 
25. Oxford Centre of Evidence-based Medicine: levels of evidence (march 2009)

http://www.cebm.net/index.aspx?o=1025 (last visit: Jan 15th 2011)

26. Ebell MH, Siwek J, Weiss BD et al. Strength of recommendation taxonomy (SORT): a patient-centered approach to grading evidence in the medical literature. J Am Board Fam Pract 2004;17:59-67

27. Monneuse O, Tissot E, Gruner L et al. Diagnosis and treatment of spontaneous group A streptococcal peritonitis. Br J Surg. 2010;97:104-8

28. Rimola A, Garcia-Tsao G, Navasa M et al. Diagnosis, treatment and prophylaxis of spontaneous bacterial peritonitis: a consensus document. J Hepatol 2000; 32: 142153

29. Javid G, Khan BA, Khan BA et al. Short course ceftriaxone therapy in spontaneous bacterial peritonitis. Postgrad Med J 1998; 74: 592-599

30. Mowat C, Stanley AJ. Spontaneous bacterial peritonitis diagnosis, treatment and prevention. Aliment Pharmacol Ther 2001; 15: 1851-1859

31. Sort P, Navasa M, Arroyo V et al. Effect of intravenous albumin on renal impairment and mortality in patients with cirrhosis and spontaneous bacterial peritonitis. N Eng J Med 1999; 341: 403-409

32. Stuart S, Booth TC, Cash CJ et al. Complications of continuous ambulatory peritoneal dialysis. Radiographics 2009; 29: 441-460

33. Lima RC, Barreira A, Cardoso FL et al. Ciprofloxacin and cefazolin as a combination for empirical initial therapy of peritoneal dialysis-related peritonitis: five-year follow-up. Perit Dial Int 2007; 27: 56-60

34. Van Ruler O, Mahler CW, Boer KR et al. Comparison of on-demand vs planned relaparotomy strategy in patients with severe peritonitis: a randomized trial. JAMA 2007; 298:865-872

35. Bodmann KF, Grabein B et al. Recommendations of the Paul-Ehrlich-society for chemotherapy for the empirical antimicrobial treatment of severe infections of adults. Eckmann C, Isenmann R, Kujath P et al.: Intra-abdominal infections. Chemother J 2010;19:217-222

36. Dupont $H$. The empiric treatment of nosocomial intraabdominal infections. Int J Infect Dis 2007; 11(S1): S1-S6

37. Harbarth S, Uckay I. Are there any patients with peritonitis who require empiric therapy for enterococcus? Eur J Microbiol Infect Dis 2004; 23: 73-77

38. Paul M, Silbiger I, Grozinsky S et al. Beta lactam antibiotic monotherapy versus lactam-aminoglycoside antibiotic combination therapy for sepsis. Cochrane Database Syst Rev 2006; 25: CD003344

39. Masterton RG, Galloway A, French G et al. Guidelines for the management of hospital-acquired pneumonia in the UK. J Anticrob Chemother 2008; 62: 5-34

40. Giske CG, Monnet DL, Cars O et al. Clinical and economic impact of common multidrug-resistant Gram-negative bacilli. Antimicrob Agents Chemother 2008; 52: 813-821

41. Chromik AM, Meiser A, Hölling J et al. Identification of patients at risk for development of tertiary peritonitis on a surgical intensive care unit. J Gastrointest Surg 2009; 13: 1358-1367

42. Mazuski JE. Antimicrobial treatment for intraabdominal infections. Expert Opin Pharmacother 2007; 8: 29332945

43. Krepel CJ, Gohr CM, Edmiston CE, Condon RE. Surgical sepsis: constancy of antibiotic susceptibility of causative organisms. Surgery 1995; 117: 505-509

44. De Waele JJ, Hoste EA, Blot SI. Blood stream infections of abdominal origin in the intensive care unit: characteristics and determinants of death. Surg Infect 2008; 9: 171177
45. Roehrborn A., Thomas L, Potreck O et al. The microbiology of postoperative peritonitis. Clin Infect Dis 2001; 33: 1513-1519

46. Nickols RL, Muzik AC. Enterococcal infections in surgical patients: the mystery continues. Clin Infect Dis 1992; 15: $72-76$

47. Halle E, Padberg J, Rosseau S et al. Linezolid-resistant Enterococcus faecium and Enterococcus faecalis isolated from a septic patient: report of first isolates in Germany. Infection 2004; 32: 182-183

48. Livermore DM. Beta-lactamases in laboratory and clinical resistance. Clin Microbiol Rev 1995; 8: 557-584

49. Lehner S, Grabein B, Pfaller P, Kopp R. Relevance of ESBL-producing pathogens for clinical surgery: diagnostics, therapy and prevention. Chirurg 2009; 80: 527-536

50. DiNubile MJ, Friedland I, Chan CY et al. Bowel colonization with resistant Gram-negative bacilli after antimicrobial therapy of intra-abdominal infections. Eur J Microbiol Infect Dis 2005; 24: 443-449

51. Sotto A, Lefrant JY, Fabbro-Peray P et al. Evaluation of antimicrobial therapy management of 120 consecutive patients with secondary peritonitis. J Antimicrob Chemother 2002; 50: 569-572

52. Driscoll JA, Brody SL, Kollef MH. The epidemiology, pathogenesis and treatment of Pseudomonas aeruginosa infections. Drugs 2007; 67: 351-368

53. Montravers P, Dupont H, Gauzit R et al. Candida as a risk factor for mortality in peritonitis. Crit Care Med 2006; 34: 646-652

54. Blot SI, Vandewoude KH, De Waele JJ. Candida peritonitis. Curr Opin Crit Care 2007; 13: 195-199

55. Blot S, Dimopoulos G, Rello J, Vogelaers D. Is Candida really a threat in the ICU? Curr Opin Crit Care 2008; 14: 600-604

56. Leon C, Ruiz-Santana S, Saavedra P et al. A bedside scoring system ("Candida score") for early antifungal treatment in nonneutropenic critically ill patients with Candida colonization. Crit Care Med 2006; 34: 730-737

57. Pelz RK, Hendrix CW, Swoboda SM et al. Double-blind placebo-controlled trial of fluconazole to prevent candidal infections in critically ill surgical patients. Ann Surg 2001; 233: 542-548

58. Eggimann P, Francioli P, Bille J et al. Fluconazole prophylaxis prevents intra-abdominal candidiasis in high-risk surgical patients. Crit Care Med 1999; 27: 1066-1072

59. Pfaller MA, Diekema DJ. Epidemiology of invasive candidiasis: a persistent public health problem. Clin Microbiol Rev 2007; 20: 133-163

60. Pappas PG, Kauffman CA, Andes D et al. Clinical practise guidelines for the management of candidiasis: 2009 update by the Infectious Diseases Society of America. Clin Infect Dis 2009; 48: 503-535

61. Whitcomb DC. Acute pancreatitis. N Eng J Med 2006; 354: 2142-2150

62. Banks PA, Gerzov SG, Langevin RE et al. CT-guided aspiration of suspected pancreatic infection: bacteriology and clinical outcome. Int J Pancreatol 1995; 18: 265-270

63. Besselink MG, Verwer TJ, Schoenmakers EJ et al. Timing of surgical intervention in necrotizing pancreatitis. Arch Surg 2007; 142: 1194-1201

64. Bassi C, Larvin M, Villatore E. Antibiotic therapy for prophylaxis against infection of pancreatic necrosis in acute pancreatitis. Cochrane Database Syst Rev 2003;(4): CD002941

65. Villatore E, Bassi C, Larvin M. Antibiotic therapy for prophylaxis against infection of pancreatic necrosis in acute pancreatitis. Cochrane Database Syst Rev 2006;(4): CD002941

66. Mazaki T, Ishii Y, Takayama T. Meta-analysis of prophylactic use in acute necrotizing pancreatitis. Br J Surg 2006; 93: 674-684 
67. Nathans AB, Curtis JR, Beale RJ et al. Management of the critically ill patient with severe acute pancreatitis. Crit Care Med 2004; 32: 2524-2436

68. De Waele JJ. A role for prophylactic antibiotics in necrotizing pancreatitis? Crit Care 2008; 12: 195

69. Gerding DN, Johnson S. Management of clostridium difficile infection: thinking inside and outside the box. Clin Infect Dis 2010;51:1306-1313

Received: February 1, 2011 / Accepted: February 25, 2011
Address for correspondence:

Priv.-Doz. Dr. med. Christian Eckmann

Klinikum Peine gGmbH, Academic Hospital of Medical University Hannover

Virchowstrasse $8 \mathrm{~h}$

D-31226 Peine

Germany

Phone: $+49 /(0) 5171 / 931530$

Fax: $\quad+49 /(0) 5171 / 931549$

Email: christian.eckmann@klinikum-peine.de 